Global Conferences Series:

Social Sciences, Education and Humanities (GCSSSEH), Volume 3, 2019

The $1^{\text {st }}$ International Conference on Education, Social Sciences and Humanities

DOI: https://doi.org/10.326/hum0220

\title{
Formation of The Character of High School Students Through The Development of Sharia-Based Economic Learning Material
}

\author{
Triesninda Pahlevi ${ }^{1}$, Luqman Hakim ${ }^{2}$, Riza Yonisa Kurniawan ${ }^{3}$, Febrika Yogie \\ Hermanto ${ }^{4}$ \\ 1, 2,3 Universitas Negeri Surabaya, Surabaya, Indonesia \\ ${ }^{4}$ Universitas Negeri Yogyakarta, Indonesia \\ (") $₫$ triesnindapahlevi@unesa.ac.id
}

\begin{abstract}
This study aims to shape the character of high school students based on Shariah values through the development of Sharia-based economic learning tools. The research methodology used is the 4D development model by Thiagarajan which consists of define, design, develop, and disseminate. The samples taken in this study were Class XI High School students in East Java Province. Learning tools developed in this study are Syllabus, Learning Implementation Plan, and student worksheet Economic learning based on Shariah values. Sharia values that shape the character of students include (1) Tawhid (Oneness of God); (2) 'Adl (Justice); (3) Nubuwwah (Prophethood); (4) Ma'ad (Results). The results of expert validation amounted to $84.3 \%$ indicating the learning device was declared feasible to be tested. The formation of student character values is seen from the attitude assessment based on Sharia values that are given treatment and not given treatment. The results showed that there were differences between the classes treated with the untreated with a significance level of $0.00<0.05$.
\end{abstract}

Keyword: student character, development of learning material, attitude assessment

\section{Introduction}

Seeing the rapid development of sharia-based business in Indonesia, the need for this is introduced early on to students. Based on data from Bank Indonesia in 2012, the growth rate of Islamic banking assets is higher than the growth of banking assets nationally. Based on data on the development of Islamic banking business activities per Province, Bank Indonesia indicates that the share of Islamic banking to the national banking industry has increased from $4 \%$ to $4.6 \%$. Not only that, from these data, Bank Indonesia shows that the development of Islamic banking is quite rapid in several regions in Indonesia. Reflected in the growth of third-party fund collection activities (DPK) and/or the distribution

Copyright (C) 2019, the Authors. Published by Redwhite Press.

Page | 218

This is an open access article under the CC BY-NC license

(http://creativecommons.org/licenses/by-nc/4.0). 
of funds that are quite high in several provinces in Indonesia, namely Kalimantan, Sulawesi, Maluku and Papua that exceed the growth rate nationally. In addition, several regions in the Java-Bali region also showed a fairly high growth with DKI Jakarta still being the main target in the development of Islamic banking businesses with a share of deposits.

Data on the development of Islamic banks shows considerable potential if this continues to be developed starting from introducing and instilling Shariah values to high school students so that they can be embedded in their soul or character. In realizing the introduction and planting of Sharia values to students can be done on learning in schools that starts from learning devices in the form of Syllabus, Learning Implementation Plan (RPP), and LKPD Economic learning based on Shariah values. The aim is to prepare human resources (SDI) which are expected to support the development of businesses based on Islamic economics in the future.

This is very possible because it is supported by the current phenomenon where the Islamic economy is very positive and massive is accepted by the community with its non-religious concept. With this phenomenon, the community becomes eager to learn and explore what and how concepts and also Islamic values. According to Saleh (2012), which makes people want to learn more about what and how Islamic values are psychological factors that originate from religious motives in addition to external factors, social and non-social environment and teachers. This is reinforced by the results of research by Hermawan (2008) dan Mubarok (2011), whose research on student perceptions in local content subjects, and the results students have a very good perception of the implementation of the Sharia Economy Local Content learning and have the desire to learn more in. Students' interest in insert economics in Islamic economics is very large at $55 \%$ and students want to learn more deeply about these subjects (Hakim, Anwar, Kurniawan, \& Pahlevi, 2019).

In encouraging the advancement of Islamic economics in the field of education and science which can then be implicitly directed towards the advancement of sharia-based business, the need to introduce sharia economic education since primary, secondary and high education in order to prepare quality human resources (SDI). Probably the obstacle faced, based on the 2013 curriculum, if it is implemented for high school students is not explicitly Islamic economics is included in the curriculum there.

In addition, Islamic economics is also not much touched or unfamiliar at the high school level. More economic discussions there are related to conventional economics. Muslikah (2009) stated that a good sharia curriculum is competency-based in the implementation of general learning based on Islamic principles which are integrated into cognitive, affective, and psychomotor competencies.

In supporting the effectiveness of economic learning that emphasizes Islamic values by considering the achievement side of cognitive, affective and psychomotor competencies, according to (Permendikbud, 2013) the learning tools used are good to use the scientific approach method. Because learning uses the scientific approach method refers more to the investigation technique of the phenomenon that occurs, acquires new knowledge, and corrects and integrates the knowledge comprehensively.

In addition, according to Bensaid \& Machouche (2012) to provide cases of information on certain Islamic topics or mastery of textbooks without opposing the thinking of students, they can provide ideas that appear that can have a good impact on student memorization. Because the learning of Islamic economics is indeed more memorizing about the Koran and the Hadith, so the learning that is done must definitely support the memorization process of the students.

The focus of the development of learning devices in the form of Syllabus, Learning Implementation Plans (RPP), and Economic Learning LKP based on five Shariah Values taken from Muhammad \& Karim 
(1999) namely Tauhid (oneness of God), 'Adl (Justice), Nubuwwah (prophethood), and Ma'ad (Results). The four Islamic values are then used as the main points to be taught to students. The aim is so that students can have Islamic characters that are in accordance with the five Islamic values.

In assessing learning objectives by instilling five sharia characters can be measured through learning outcomes and student learning interests. Learning outcomes are abilities possessed by students after receiving learning experiences (Sudjana in Farliana, 2015). These learning outcomes can measure the increase in the cognitive, affective and psychomotor fields of students so that the five sharia characters in students can be measured which are the results of learning devices in the form of a syllabus, RPP, and LKPD that have been compiled.

There are also things that need to be considered in supporting the success of instilling five sharia characters with students, namely through an interest in learning. Sabri (dalam Umaryati, 2017) mentions that interest is the tendency of people to carry out certain activities continuously with pleasure. The indicators of interest in learning according to (Hurlock, 1991) are students' interest in learning, responsibility, student response, collaboration and the level of student satisfaction after learning.

With these two things, it is expected that learning devices in the form of Syllabus, Learning Implementation Plans, and LKPD developed can be a measuring tool in planting five sharia characters to students, which later, it can become the foundation of student character in everyday life. If it has become an embedded character for students, it is very likely that this will be one of the basic foundations in developing sharia behavior that supports various sharia economic activities in Indonesia. So that Islamic economics in Indonesia can become more developed with the character of Islamic society in accordance with the five characters of sharia that are instilled early on to high school students.

\section{Method}

The research method used is the $4 \mathrm{D}$ development model by Thiagarajan which has a 4-step process, namely define, design, develop, and disseminate (Anggraini \& Sukardi, 2016). The samples taken in this study were Class XI High School students in East Java Province. The sampling technique uses purposive sampling with certain considerations (Sugiyono, 2016).

The development of insert economic learning devices of Islamic values uses the development model of Thiagaradjan (1974)) (Rochmad, 2012), with a description of the following stages:

1. Define; identification of the needs of the Islamic Economics learning device in the economic subjects of the Class XI High School of the Science Department, through preliminary studies and Focus Group Discussion (FGD), high school economics teachers, sharia economists, and researchers.

2. Design; Preparation of syllabus, lesson plans, and supplementary materials for teaching Islamic Economics

3. Develop; Test expert draft 1 (syllabus, lesson plan, and supplement of Islamic Economics Teaching Materials), and limited trials on sample schools and the final results of learning devices based on Syllabus, RPP, and Economic LKPD Insert Sharia Class XI High School Science Specialization.

4. Disseminate; the spread of insert economic subjects in Islamic economics learning devices in East Java High Schools.

Data collection techniques in this study used questionnaires, interview guidelines, and observation checklists. Data analysis techniques in the form of questionnaires were analyzed using simple statistics such as percentages and averages. Observation data is described and interpreted qualitatively. The document data is analyzed according to the analysis guidelines. 
Collecting data in experimental research using instruments to assess student attitudes towards Islamic economic values before and after implementation. Data analysis was performed by inferential statistical analysis. The pretest and posttest results were analyzed by quantitative analysis of $\mathrm{t}$-test with the research hypothesis that there were differences in student attitudes before and after being given a treatment of Islamic economic values.

\section{Result and Discussion}

Development of learning devices includes Syllabus, RPP (Learning Implementation Plan), and LKPD (Student Worksheet) Islamic Economics Learning Tools in Cross-Specialization Economics Subjects Based on High School Scientific Approach The Science Department has been developed by researchers in accordance with the Plomp development model. Test evaluation, and revision, Implementation. In this study, it only reached the Realization / Construction stage.

Based on the results of the feasibility of the expert test or the second feasibility in the very feasible category with a percentage of $91.48 \%$ by experts who are lecturers and $94.28 \%$ by experts who are economics teachers so the average percentage is $92.88 \%$. Likewise with the component of RPP eligibility included in the very feasible category in the expert test or the second feasibility with the percentage of sharia economics lecturers $88.89 \%$ and $91.11 \%$ by experts who are economics subject teachers so that the average percentage of eligibility RPP is $90 \%$. The feasibility component of the LKPD is in the very feasible category in the expert test or the second feasibility with the percentage of sharia economics lecturer experts $88 \%$ and $95 \%$ by experts who are economics subject teachers so that the average feasibility percentage of LKPD is $91.5 \%$. In general, the results of the feasibility average amounted to thus it can be stated that the learning devices developed were declared feasible by experts.

Furthermore, in measuring the effectiveness of learning devices, as has been stated above, an attitude assessment of Islamic economic values is carried out before and after being applied by measuring the pretest and posttest. The results of the $t$-test amounted to $0.00<0.05$ this means that students' attitudes experienced differences before and after the implementation of the Islamic economic insert learning device applied to Sharia. Islamic economic learning tools have a positive impact on improving student attitudes (Arifah, Haryono, \& Nurhayati (2015); Supriyanto (2012)). Understanding of Islamic economics is higher after conducting Islamic economics learning, this is because at the time of learning students are introduced earlier about the principles of economics and Islamic culture. This is in accordance with the opinion of Bensaid \& Machouche (2012) that multicultural education, in this case, is Islamic religious education, and the introduction of Islamic culture can increase students' understanding of Islamic economics.

Indicators measuring attitudes based on sharia values are (1) Tawhid (oneness of God); (2) 'Adl (Justice); (3) Nubuwwah (prophethood); and (4) Ma'ad (Results) (Muhammad \& Karim, 1999).

a. Tawhid (Oneness of God)

Three basic principles of monotheism include (1) the world and its contents belong to God and human beings only have absolute leadership and management rights; (2) all creatures of God must obey and realize life in the world is only temporary, so that people will always be grateful and set aside some fortune to those who have the right to receive it; (3) by realizing life in the world is only temporary, then humans in carrying out their activities must consider the aftermath.

b. 'Adl (Justice) 
The implication of justice in the Islamic economy is the fulfillment of basic needs for every society, respectable sources of income, equitable distribution of income and wealth, and the growth of good economic stability.

c. Nubuwwiah (Prophethood)

Prophetic traits that can be implicated in Islamic economic activities are Siddiq (true, honest, valid), trustworthiness (trustworthy, credibility), fathanah (intelligence, wisdom, professionalism, intellectuality), and tabligh (communicative, transparent, marketable).

d. Ma'ad (Results)

In reality, humans were created to struggle with work and activity, and charity. The concept of economic and business is to get profit/motivation as motivation for business people. This profit can be obtained in the world and in the hereafter.

\section{Conclusions}

Based on the results of the feasibility test of sharia insert economic learning which includes Syllabus, RPP (Learning Implementation Plan), and LKPD on the economic material of the SMA XA SMA specialization group, as well as student trials, it can be concluded that sharia insert economic subjects learning devices have met feasibility standards to be used in sharia economic learning across science specialization. the material that is inscribed is in accordance with the Basic Competence in the 2013 Curriculum learning standard. In the RPP (Learning Implementation Plan) the sharia insert economy has met the feasibility standard to be used in economic learning in class XI science interest groups. RPP Syariah insert economy has been adapted to the concept of 21st-century learning so that it is effectively used in learning activities. LKPD (Student Worksheet) which contains material and practice questions have quality and are suitable for use in sharia insert economic learning. LKPD contains economic material that is inscribed with sharia material and has been adapted to the basic economic competencies of class XI science interest groups. Based on statistical analysis and hypothesis testing sharia economic learning devices have a significant influence on student character formation through attitudinal attitudes adapted to Islamic economic values.

\section{References}

Anggraini, F., \& Sukardi. (2016). Pengembangan Modul Pembelajaran Kewirausahaan Model Student Company di SMK Negeri 1 Godean. Jurnal, 6(1), 24-30.

Arifah, K. N., Haryono, H., \& Nurhayati, N. D. (2015). Upaya Peningkatan Keaktifan Siswa Dan Prestasi Belajar Dengan Metode Constructive Controversy (Cc) Pada Materi Elektrolit Dan Nonelektrolit Bagi Peserta Didik Kelas X Mia 2 Semester Genap Sma Batik 2 Surakarta Tahun Pelajaran 2013/2014. Jurnal Pendidikan Kimia, 4(2), 122-129.

Bensaid, B., \& Machouche, S. B. T. (2012). Exploring the relationship between Islamic religious learning and community. Multicultural Education \& Technology Journal, 7(4), 317-332.

Farliana, N. (2015). Peningkatan Keaktifan Dan Hasil Belajar Materi Analisis Swot Melalui Talking Chips Dengan Media Audio Visual. In Seminar Pendidikan Ekonomi dan Bisnis (p. (Vol. 1, No. 1).).

Hakim, L., Anwar, M. K., Kurniawan, R. Y., \& Pahlevi, T. (2019). Economic Lessons Insert the Islamic Economy : How the Interest Action in Science High School Student Majoring ?, (1), 3-9.

Hermawan, E. (2008). Persepsi Siswa dan Guru Tentang Ekonomi Syariah Melalui Sistem Pembelajaran di Sekolah (studi pada SMPN 1 Kota Tasikmalaya. UIN Syarif Hidayatullah.

Hurlock, E. . (1991). Psikolgi Perkembangan Suatu Pendekatan Sepanjang Rentang Kehidupan. Jakarta: Jakarta : Penerbit Erlangga. 


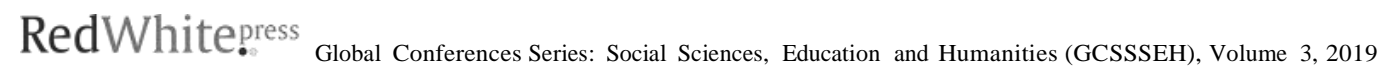

Kristanti Ely A. (2012). Pengembangan Perangkat Pembelajaran Bioentrepreneurship Pembuatan Makanan Dari Limbah Cair Pengolahan Kedelai. Journal of Innovative Science Education 1 (JISE 1), 2(2012), 112-118.

Mubarok, A. H. (2011). Persepsi Siswa Terhadap Pelaksanaan Pembelajaran Muatan Lokal Ekonomi Syraiah di SMPN 2 Kota Tasikmalaya. UIN Syarif Hidayatullah.

Muhammad, A. ., \& Karim, F. A. . (1999). Sistem, Prinsip, dan Tujuan Ekonomi Islam. Bandung: CV Pustaka Sejati.

Muslikah, R. (2009). No TitleImplementasi Kurikulum Syariah Berbasis Kompetensi di Sekolah Dasar Muhammadiyah Terpadu (SDMT) Masaran Sragen. UIN Sunan Kalijaga.

Rochmad. (2012). Desain Model Pengembangan Perangkat Pembelajaran Matematika. Jurnal Kreano, 3(1), $59-72$.

Saleh, I. (2012). Urgensi Mempelajari Ekonomi Islam (Studi Motivasi Belajar Ekonomi Islam pada Anggota Kelompok studi Ekonomi Islam Fakultas Ekonomika dan Bisnis Universitas Diponegeoro Semarang. Universitas Diponegoro.

Sugiyono. (2016). Metode Penelitian Kuantitatif, Kualitatif dan RED. Bandung: PT Alfabet.

Supriyanto, A. (2012). Persepsi Guru Matematika Terhadap Kurikulum Sekolah Syariah Serta Implikasinya Dalam Pembelajaran (Studi kasus pada SD Muhammadiyah Program Khusus Kottabarat Surakarta tahun 2012). Universitas Muhammadiyah Surakarta.

Umaryati, S. (2017). Pengaruh pembelajaran ekonomi islam terhadap minat mahasiswa menabung di Bank Syariah: studi pada mahasiswa IPS UIN Syarif Hidayatullah Jakarta. UIN Syarif Hidayatullah Jakarta. 